\title{
GAMBARAN PENGGUNAAN ALAT KONTRASEPI IMPLAN PADA WANITA USIA SUBUR DI CILENDEK BARAT KECAMATAN BOGOR BARAT KOTA BOGOR TAHUN 2019
}

\author{
Ana Kurnia Irawan', Fenti Dewi Pertiwi ${ }^{2}$ \\ ${ }^{1}$ Konsentrasi Kesehatan Reproduksi dan Kesehatan Ibu Anak (KIA), Program Studi Kesehatan Masyarakat, \\ Fakultas Ilmu Kesehatan, Universitas Ibn Khaldun Bogor. Email: anakurniairawan79@gmail.com \\ ${ }^{2}$ Konsentrasi Kesehatan Reproduksi dan Kesehatan Ibu Anak (KIA), Program Studi Kesehatan Masyarakat, \\ Fakultas Ilmu Kesehatan, Universitas Ibn Khaldun Bogor. Email: fenti.dewi.pertiwi@gmail.com
}

\begin{abstract}
Abstrak
Laju pertumbuhan penduduk ditentukan oleh tingkat kelahiran dan kematian. Tingginya tingkat kelahiran menyebabkan tingkat kematian penduduk rendah, yang berdampak pada semakin tingginya ledakan penduduk. Tujuan penelitian untuk mengetahui gambaran penggunaan alat kontrasepi implant Wanita Usia Subur (WUS). Studi ini menggunakan rancangan kualitatif dengan Rapid Assesment Procedure (RAP). Pengumpulan data dengan teknik wawancara mendalam dan observasi. Wawancara mendalam dilakukan pada informan sebanyak 18 informan. Hasil penelitian menunjukan bahwa gambaran penggunaan alat kontrasepsi implan wanita usia subur yaitu: sebagian besar mengetahui alat kontrasepsi implan, sebagian besar merespon baik, sebagian besar mendapatkan informasi, sebagian besar tidak mengeluarkan biaya, sebagian besar mendapatkan dukungan dari suami. Kesimpulan gambaran penggunaan alat kontrasepi implant wanita usia subur mengetahui alat kontrasepi,merespon baik,dukungan baik,mendapatkan informasi,akses ke pelayanan terjangkau,dukungan baik dari suami. Saran bagi peneliti selanjutnya untuk menambah informan serta melakukan probing lebih banyak.
\end{abstract}

Kata Kunci : Implan, KB, WUS.

\section{PENDAHULUAN}

Pertumbuhan penduduk terus meningkat merupakan salah satu masalah bagi negaranegara di dunia, khususnya negara berkembang. Secara sederhana dapat disebutkan bahwa penduduk akan terus bertambah selama jumlah kelahiran melebihi dari jumlah yang meninggal. Perserikatan Bangsa bangsa (PBB) memproyeksikan bahwa populasi dunia pada tahun 2015 mencapai 7,5 milyar dan akan mencapai angka 9,7 milyar pada tahun 2050 yang didorong oleh pertumbuhan penduduk di negara- negara berkembang. Meningkatnya populasi penduduk di dunia maka akan terjadi lonjakan besar yang tidak hanya menurunkan kualitas kehidupan manusia, namun juga dapat mengancam lingkungan hidup dan kehidupan sehat (Ruspawan dkk, 2017)

Laju pertumbuhan penduduk di Indonesia dari tahun ke tahun semakin meningkat, dimana pada tahun 2013 jumlah penduduk Indonesia sebanyak 248.80 juta jiwa, dan meningkat menjadi 252.20 juta jiwa pada tahun 2014 (BPS, 2015). Laju pertumbuhan penduduk ditentukan oleh tingkat kelahiran dan kematian. Tingginya tingkat kelahiran menyebabkan tingkat kematian penduduk rendah, yang berdampak pada semakin tingginya 
ledakan penduduk (Febriyanti dkk, 2018).

Indonesia memiliki angka kelahiran diatas rata-rata negara ASEAN dan terus mengalami fase stagnan dalam 4 periode terakhir yaitu 2002, 2007, 2012 dan 2013 sebesar 2,6 anak per 1000 wanita usia subur. Melihat kondisi ini, target menurunkan angka kelahiran menjadi 2,11 per 1000 wanita usia subur pada tahun 2015 memerlukan usaha yang keras. Salah satu upaya konkrit dalam menurunkan angka kelahiran adalah penerapan Keluarga Berencana (KB) dengan menggunakan kontrasepsi (Kemenkes, 2013).

Penggunaan MKJP di Indonesia jauh dari target (26,7\%) dan menurun tiap tahunnya dari 13,7\% pada tahun 1991 sampai 10,6\% pada tahun 2012 (Kemenkes,2013). Pada tahun 2013 berdasarkan survei mini Badan Kependudukan dan Keluarga Berencana (BKKBN), cakupan MKJP di Indonesia hanya sebesar 12,4 \% dengan persentase berdasarkan jenis metode yaitu susuk (implant) KB (5,2\%), AKDR (Alat Kontrasepsi Dalam Rahim)/Intrauterine Device (IUD) (4,7), dan Metode Operasi Wanita (MOW) (2,2\%), padahal target MKJP yang diharapkan dapat dicapai adalah 26,7\%.

Hasil Survei Badan Pusat Statistik (BPS) Jawa Barat tahun 2015 persentase Pasangan Usia Subur (PUS) berumur 15-49 tahun yang menggunakan alat kontrasepsi KB di Provinsi Jawa Barat pada tahun 2015 tercatat sebanyak 7.031.902 peserta KB aktif dengan jumlah Pasangan Usia Subur (PUS) sebanyak 9.715.469 dengan rincian masing-masing per metode kontrasepsi Intra Uterine Device (IUD) sebanyak 798.654 peserta, Metode Operasi Wanita (MOW) sebanyak 177.64 peserta, Metode Operasi Pria (MOP) sebanyak 53.266 peserta, Kondom sebanyak 334.039 peserta, Implan sebanyak 392.978 peserta, Suntikan sebanyak 3.610.253 peserta, Pil sebanyak 1.665.048 peserta (BPS Jawa Barat, 2015).

Pencapaian Peserta KB aktif di Kota Bogor dengan jumlah wilayah 6 Kecamatan yaitu kecamatan Bogor Barat, Bogor Selatan, Bogor Tengah, Tanah Sereal, Bogor Utara, dan Bogor Timur, menurut Dinas Pengendalian Penduduk dan Keluarga Berencana (DPPKB), cakupan target pencapaian KB aktif tahun 2018 yaitu 118.815 orang (76,35\%). Bogor Barat menempati ke 3 terendah dari metode Implant sebesar 113 orang dari 6 Kecamatan di Kota Bogor. Hasil data di Kecamatan Bogor Barat memiliki 16 kelurahan, yaitu: Menteng, Sindang Barang, Bubulak, Margajaya, Balumbang Jaya, Situ Gede, Semplak, Cilendek Barat, Cilendek Timur, Curug Mekar, Curug, Pasir Jaya, Pasir Mulya, Pasir Kuda, Gunung Batu dan Loji. Berdasarkan data PLKB kecamatan Bogor barat julmah Pasangan Usia Subur (PUS) dalam penggunaan Alat Kontrasepsi Implant menyatakan bahwa Kelurahan Cilendek Barat merupakan wilayah yang memiliki akseptor terendah yaitu $42,8 \%$.

Tujuan Umum dari penelitian ini adalah untuk mengetahui informasi yang mendalam mengenai gambaran penggunaan alat kontrasepsi Implan pada wanita usia subur (WUS) di Kelurahan Cilendek Barat Kecamatan Bogor Barat Tahun 2019.

Penelitian ini dilakukan untuk mengetahui Gambaran penggunaan alat kontrasepsi Implant pada pasangan usia subur di kelurahan Cilendek Barat kecamatan Bogor Barat. Populasi penelitian ini adalah wanita usia subur yang tinggal di wilayah kelurahan Cilendek Barat dengan jumlah sampel sebanyak 18 informan. Penelitian ini merupakan jenis penelitian kualitatif yang akan dilakukan di wilayah kelurahan Cilendek Barat kecamatan Bogor Barat pada bulan Januari sampai Maret tahun 2019. 


\section{METODE}

Penelitian ini merupakan penelitian yang akan mengambarkan pengunaan alat kontrasepsi implant pada wanita usia subur dengan menggunakan metode kalitatif deskriptif. Rancangan yang digunakan pada penelitian ini adalah Rapid Assesment Procedure (RAP).

Populasi dalam penelitian ini adalah Wanita Usia Subur (WUS) di wilayah kerja Kelurahan Cilendek Barat tahun 2019. Berdasarkan jumlah wanita usia subur di Kelurahan Cilendek Barat Bogor barat terdapat 2.883 wanita usia subur, yang dijadikan sampel penelitian ini hanya wanita usia subur sebanyak 8 responden, terdiri dari wanita usia subur yang menggunakan alat kontrasepsi Implan dan wanita usia subur yang tidak menggunakan alat kontrasepsi Implan. Sampel yang telah digunakan, berjumlah 18 orang informan. Penelitian ini terdiri dari 6 variabel yaitu variabel pengetahuan, sikap, biaya, akses ke pelayanan kesehatan, sumber informasi, dan dukungan suami. Instrumen penelitian yang digunakan dalam penelitian ini berupa pedoman wawancara, alat perekam suara, kertas dan alat tulis, kamera sebagai alat dokumentasi.

\section{HASIL}

\section{a. Gambaran Pengetahuan}

Variabel pengetahuan ini meliputi definisi $\mathrm{KB}$, definisi implan, serta manfaat dan efek samping. Dari hasil wawancara dengan informan mengenai definisi KB, semua informan baik yang memilih implan atau yang tidak memilih implan menyampikan bahwa KB adalah untuk menjarangkan kehamilan, sedangkan mengenai definisi kontrasepsi implan, 7 (tujuh) dari 8 (delapan) informan inti menyampaikan bahwa kontrasepsi implan adalah alat jangka panjang yang dipasang ditangan. Selanjutnya mengenai efek samping serta manfaat, informan menyampaikan bahwa tidak ada efek samping pada saat penggunaan alat kontrasepsi dan merasa nyaman.

" $k b$ tuh yaa palingan yaa untuk kesehatan kita juga yaa soalnya buat mencegah kehamilan gitu kan euhehehe apa yaaa, ya saya tau nya Cuma begitu aja sihh, euhhh alatnya dipasang di tangan, kalo menurut saya sih merasa cocok kalp setiap bulan juga haid nya lancar, pokoknya cocok gitu buat badan juga ga buat gemuk gitu ehehehehe ga melar gitulah " (Informan Inti A4)

\section{b. Gambaran Sikap}

Variabel sikap ini meliputi alasan informan untuk memilih kontrasepsi, cara untuk ikut serta dalam program KB dan yang seharusnya ikutserta dalam berKB. Dari hasil wawancara mendalam kepada informan inti yang memilih implan, 1 (satu) dari 4 (empat) informan menyampaikan bahwa alasan untuk memilih implan karena adanya ajakan dari teman atau PLKB. sedangkan 1 (satu) dari 4 (empat) informan inti yang tidak memilih implan menyampaikan bahwa tidak memilih implan karena masih merasa takut. Dan secara umum informan inti menyampaikan cara ikutserta dalam program KB adanya ajakan dari teman dan kader. Selanjutnya mengenai siapa yang seharusnya ikut serta dalam berKB, 6 (enam) dari 8 (delapan) menyampaikan bahwa yang harus ikutserta dalam berKB adalah semua pasangan suami istri.

"ya ih heheh ya kalau menurut saya sih semua orang yang sudah menikah ya masuk dalam 
program KB gitu soalnya kan pertumbuhan penduduk semakin kesini semakin meningkat. Lagi pula sekarang kan udah banyak yang KB gratis kaya implan, ya apa salahnya kalau kita ikut dalam program KB" (Informan Inti A4)

\section{c. Gambaran Sumber Informasi}

Variabel ini menanyakan mengenai sumber informasi yang didapatkan oleh informan mengenai alat kontrasepsi implan. Berdasarkan hasil wawancara mendalam pertanyaan informan inti secara umum menyatakan Informasi yang didapatkan oleh informan dari tetangga, Bidan, Kader, bu RT, bu Rw dan PLKB.

"ya dari bu RT dari Kader dari PLKB juga, jadi ya karena saya pengen ikut KB terus jadi ya banyak yang ngasih tau ke saya" (Informan Inti A1)

\section{d. Gambaran Biaya}

Variabel ini menanyakan mengenai biaya yang dikeluarkan oleh informan untuk pemasangan alat kontrasepsi. 2 (dua) dari 8 (delapan) informan inti menyampaikan bahwa biaya yang dikeluarkan oleh informan untuk memasangan alat kontrasepsi dengan biaya sendiri. Sedangkan 6 (enam) dari 8 (delapan) informan menyampaikan pemasangan alat kontrasepsi secara gratis pada saat pelayanan safari KB.

"dari ini euh ya pake uang saya atuh engga gapake gituan kan dulu kan belum ada ini apa bpjs kaya gitu" (Informan B1)

\section{e. Gambaran Akses ke pelayanan}

Variabel ini menanyakan mengenai jarak informan menuju akses pelayanan kesehatan. Berdasarkan hasil wawancara mendalam pernyataan informan inti secara umum menyatakan akses ke pelayanan kesehatan terhadap jarak tempuh dari rumah informan ke pelayanan kesehatan menyampaikan jarak tempuh dari rumah ke pelayanan kesehatan cukup terjangkau.

"ya lumayan sih kalau dari sini mah jauh, tapi euh ya terjangkau lah" (Informan Inti A1)

\section{f. Gambaran Dukungan Suami}

Variabel ini menanyakan mengenai bentuk dukungan suami serta komunikasi antara suami dan istri pada saat menentukan pilihan dalam memilih kontrasepsi. 1 (satu) dari 8 (delapan) informan inti tidak memilih implan menyampaikan bahwa suami tidak mendukung informan pada saat informan memilih informan yang digunakan saat ini. Sedangkan 7 (tujuh) dari 8 (delapan) informan inti menyampaikan bahwa adanya dukungan positif dari suami.

"euh suami sih sebenernya ga setuju soalnya katanya ga nyaman pas lagi berhubungannya kaya ada yang ngeganjel jadi nyuruh saya pake KB suntik aja tapikan euh saya badannya udah gede takut nanti tambah gede" (Informan Inti B2)

\section{PEMBAHASAN}

\section{a. Pengetahuan}

Berdasarkan hasil wawancara mendalam 7 (tujuh) dari 8 (delapan) informan inti mengetahui mengenai definisi KB, definisi implan serta manfaat dan efek samping. Namun 1 (satu) dari 8 
(delapan) informan inti menyampaikan bahwa informan tidak tahu mengenai definisi implan. Hal ini tidak sejalan dengan penelitian yang dilakukan oleh Gustikawati (2014) yang menyatakan bahwa rendahnya penggunaan MKJP berupa implan dengan pengetahuan.

\section{b. Sikap}

Berdasarkan hasil wawancara mendalam secara umum semua informan inti merespon baik terhadap program KB dan mengenai penggunaan alat kontrasepsi implan. Namun 1 (satu) dari 8 (delapan) informan inti yang tidak memilih implan beralasan bahwa informan masih takut untuk memilih alat kontrasepsi implan.

Hal ini sejalan dengan penelitian yang dilakukan oleh Gustikawati (2014) menyatakan bahwa adanya hubungan sikap seseorang terhadap penggunaan alat kontrasepsi.

\section{c. Sumber Informasi}

Hasil wawancara mendalam yang dilakukan dari 8 (Delapan) informan inti yang diwawancara menyampaikan informasi yang didapatkan mengenai alat kontrasepsi dari petugas PLKB, Kader dan Bidan yang dilakukan di Posyandu. Sehingga sumber informasi tersebut akan memberikan respon baik terhadap informan serta menambah pengetahuan informan mengenai KB dan kontrasepsi implan.

Hal ini sejalan dengan hasil penelitian yang dilakukan oleh Subiyatun (2011) yang menyampaikan bahwa ada hubungan antara pemberian informasi dengan pemilihan metode kontrasepsi rasional di wilayah proyek SM-PFA di 10 Kabupaten Jawa Tengah dan Jawa Timur.

\section{d. Biaya}

Hasil wawancara mendalam 6 (enam) dari 8 (delapan) informan inti menyampaikan bahwa biaya yag digunakan pada saat pemasangan alat kontrasepsi dilakukan secara gratis tanpa adanya pengeluaran biaya sedangkan 2 (dua) dari 8 (delapan) informan inti menyampaikan bahwa biaya yang dikeluarkan pada saat pemasangan alat kontrasepsi yaitu dengan biaya sendiri. Adanya biaya dari APBN atau APBD sehingga informan bisa melakukan secara gratis ketika pemasangan alat kontrasepsi pada saat pelayanan safari KB.

Hal ini tidak sejalan dengan penelitian yang dilakukan oleh Febriyanti dkk (2018) yang menyampaikan bahwa ada faktor biaya yang mempengaruhi akseptor untuk tidak menggunakan alat kontrasepsi implan dengan alasan biaya yang mahal.

\section{e. Akses Ke Pelayanan Kesehatan}

Hasil wawancara mendalam dari 8 (delapan) informan inti menyampaikan bahwa jarak yang dibutuhkan untuk sampai ke pelayanan kesehatan cukup terjangkau dengan jarak sekitar $2 \mathrm{~km}$. Sesuai dengan letak dan keadaan geografis kelurahan Cilendek Barat yang posisinya sangat strategis dekat dengan Pusat Kesehatan Masyarakat (Puskesmas).

Sejalan dengan penelitian yang dilakukan oleh Ekarini (2008) menyampaikan bahwa dari hasil wawancara mendalam terungkap bahwa lokasi pelayanan KB mudah dijangkau oleh responden karena alat transportasi umum sudah banyak dan letaknya yang strategis. 


\section{f. Dukungan Suami}

Hasil wawancara mendalam yang dilakukan 7 (tujuh) dari 8 (delapan) informan kunci menyampaikan bahwa suami mendukung untuk istri ikut serta dalam program KB dan memilih alat kontrasepsi sesuai kenyamanan dan keamanan dari istri. Dukungan yang dikatakan oleh informan kunci, selagi suami atau istri merasa nyaman pada saat menggunakan alat kontrasepsi suami selalu memberikan izin kepada istri. Sedangkan 1 (satu) dari 8 (delapan) informan kunci menyampaikan bahwa suami tidak mengizinkan istri untuk menggunakan KB yang pada saat itu dipakai oleh istri.

Hal ini tidak sejalan dengan penelitian yang dilakukan oleh Ni Made dan Angela (2018) yang menyatakan bahwa tidak memilih alat kontrasepsi implan karena tidak didukung oleh suami dengan alasan seperti pendapatan suami dalam sebulannya hanya mencukupi untuk keperluan rumah tangga dan kebutuhan anak sekolah saja.

\section{KESIMPULAN}

Hasil penelitian ini dapat disimpulkan bahwa gambaran pengetahuan wanita usia subur di kelurahan Cilendek Barat sebagian besar informan mengetahui mengenai definisi KB, implan dan efek samping serta manfaat. Gambaran sikap wanita usia subur yang baik, sumber informasi wanita usia subur sebagian besar dari PLKB dan Bidan, biaya yang dikeluarkan sebagian besar secara gratis pada saat pelayanan safari KB, akses ke pelayanan kesehatan secara umum terjangkau, dukungan suami sebagian besar mendapatkan dukungan positif dari suami.

\section{DAFTAR PUSTAKA}

Bakri, I., Sari, M. M., \& Pertiwi, F. D. (2019). Hubungan Dukungan Suami Dengan Pemberian Asi Eksklusif Di Wilayah Kerja Puskesmas Sempur Kota Bogor Tahun 2018. Promotor, 2(1), 27. https://doi.org/10.32832/pro.v2i1.1786

D. T. Agina, F. D. Pertiwi and I. Avianty, "Faktor - Faktor Yang Berhubungan Dengan Perilaku Penggunaan Vapor di Kalangan Siswa Sekolah Menengah Kejuruan Bina Sejahtera 2 Kota Bogor," PROMOTOR Jurnal Mahasiswa Kesehatan Masyarakat, vol. 2, no. 2, pp. 101-111, 2 April 2019.

Febriyanti N M A \& Febrianti A N E . 2018. Faktor-faktor Yang Mempengaruhi Akseptor Tidak Menggunakan Alat Kontrasepsi Implant. Jurnal Genta Kebidanan. Volume 8 Nomor 1

Febriani E G. 2018. Faktor-faktor Yang Berhubungan Dengan Penggunaan Alat Kontrasepsi Pada Wanita Usia Subur (WUS) Beragama Islam di Kelurahan Pasir Kuda Kecamatan Bogor Barat Tahun 2018.Fakultas Ilmu Kesehatan. Universitas Ibn Khaldun Bogor

Fitrianingtyas, Pertiwi, dan Rachmania, W. Faktor-Faktor yang Berhubungan dengan Kejadian Kurang Energi Kronis (KEK) pada Ibu Hamil di Puskesmas Warung Jambu Kota Bogor. HEARTY Jurnal Kesehatan Masyarakat. 2018;6(2):1-8.

Fartaeni, F., Pertiwi, F. D., \& Avianty, I. (2018). Hubungan Pengetahuan, Sikap dan Dukungan Suami Terhadap Pemberian ASI Eksklusif Di Desa Pabuaran Kecamatan Gunung Sindur. Healty Jurnal Kesehatan Masyarakat, 6(1). https://doi.org/10.32832/hearty.v6i1.1255

Gustikawati N dkk. 2014. Faktor penghambat dan pendukung penggunaan alat kontrasepsi implant di wilayah puskesamas I Denpasar Utara. Universitas Udayana.Volume 27 


\section{Nomor 2}

Gustikawati N dkk. 2014. Faktor penghambat dan pendukung penggunaan alat kontrasepsi implant di wilayah puskesamas I Denpasar Utara. Universitas Udayana.Volume 27 Nomor 2

Kemnkes RI. 2015. Profil Kesehatan Indonesia. Jakarta; Kemnkes RI

Kusnadi NR, Rachmania W, Pertiwi FD. Faktor-Faktor Yang Berhubungan Dengan Pemilihan Metode Kontrasepsi Suntik Pada Peserta KB Aktif Di Kelurahan Mekarwangi Kecamatan Tanah Sareal Kota Bogor Tahun 2019. Promotor. 2019;2(5):402-9.

Pertiwi, F. D., Hariansyah, M., \& Prasetya, E. P. (2019). FAKTOR RISIKO STUNTING PADA BALITA DIKELURAHAN MULYAHARJA TAHUN 2019. PROMOTOR, 2(5). https://doi.org/10.32832/pro.v2i5.2531

Pertiwi, F. D., Rahman, R. M., \& Lestari, D. W. (2018). Pemberdayaan masyarakat melalui bidang literasi di Desawaru Jaya. Jurnal ABDI DOSEN: Jurnal Pengabdian Pada Masyarakat, 2(2), 129-137. https://doi.org/10.32832/abdidos.v2i2.170

Pertiwi, F. D., \& Farihah, N. (2017). Hubungan Lingkungan Dengan Kejadian Infeksi Saluran Pernafasan Akut (Ispa) Pada Balita Di Wilayah Kerja Uptd Puskesmas Semplak Tahun 2016. Hearty, 5(2). https://doi.org/10.32832/hearty.v5i2.1056

Pertiwi FD, Isnawati. gambaran pengetahuan dan sikap ibu hamil tentang tanda bahaya kehamilan di Puskesmas Caringin Kabupaten Bogor tahun 2015. HEARTY Jurnal Kesehatan Masyarakat Vol.5 No.1 2017.

Rachmania, W., Kurniawan, D., \& Pertiwi, F. D. (2019). Gambaran Tingkat Pengetahuan Tentang Implan Pada Wanita Usia Subur Di Kelurahan Katulampa Kecamatan Bogor Timur Kota Bogor. Hearty, 7(1), 1-11. https://doi.org/10.32832/hearty.v7i1.2304

Ruspawan I D M \& Rahayu I G A D P. 2017. Persepsi dan Sumber Ekonomi Yang Mempengaruhi Rendahnya WUS Memilih Implant Sebagai Alat Kontrasepsi. Jurnal Gema Keperawatan.Volume 10 Nomor 2

Siti HS, Fenti DP, Ichayuen A. Gambaran Pengetahuan Orangtua, Dukungan Keluarga, Dan Status Imunisasi Terhadap Kejadian Difteri Pada Balita Di Wilayah Puskesmas Cileungsi Kabupaten Bogor Tahun 2018. Jurnal Mahasiswa Kesehatan Masyarakat. 2019. 